ticularly, growth has been rapid and, indeed, the frontiers have already advanced since the sections were written. In the first, Heller gives a thorough and masterly survey of neurohypophysial hormones. In the second, Phillips and Bellamy give an excellent account of the adrenocortical hormones throughout the vertebrates. Both chapters show the real value of comparative endocrinology and the insight gained by investigating many species of vertebrates, and thus correcting the myopia induced by restricted studies of the laboratory rat. Enormous labour has gone into the elucidation of the mode of action of insulin and naturally much of it was expended on laboratory mammals. However, here, too, F. G. Young shows, in an authoritative section, how other species, for example amphibia and the toadfish, contribute to the problem about which, as he says, so disappointingly little is known.

Other subjects have been firmly established, in the comparative sense, for many years. These are covered by the sections on thyroid hormones by Gorbman, on female gonadal hormones by Velle, on male hormones by van Oordt, on chromaffin cell hormones by von Euler, and on chromatophoric principles of the pituitary by Karkun and Landgrebe. This last area lay fallow for some time, but the recent elucidation of the structure of melanocytestimulating substances from the pig pituitary has again brought it to the forefront. In the section on the physiology of adenohypophysial hormones, Knobil and Sandler faced the task of compressing a wealth of information into a short space. 'This part thus suffers, as does Fortier's on the hypothalamic control of the anterior pituitary, by a compactness which does not allow of full development of the comparative pattern.

At the other end of the scale, Greep's paper on the parathyroid shows that here the comparative field has been almost completely neglected and such work that has been done rests too heavily on the mammals. In a thorough historical survey, Greep covers the whole of the literature, and his essay should provide an admirable starting point for those who, for example, wish to find out more about the calcium metabolism of fish, for it seems that parathyroids, as such, only appear with the tetrapods.

Von Euler and Heller, the editors, are to be congratulated for bringing together, in this first volume of Comparative Endocrinology, an excellent group of endocrinologists who have shown that both excitement and rewards can result, not so much from leaving the laboratory mammals, but by extending investigations throughout the vertebrates. Placed on the shelf with three recent text-books on comparative endocrinology, the proceedings of the three international symposia and the Journal of Endocrinology and General and Comparative Endocrinology, this volume testifies that the field of study has arrived. I. Chester Jones

\section{ORIGINS AND EVOLUTION OF CATTLE}

\section{Man and Cattle}

Proceedings of a Symposium on Domestication at the Royal Anthropological Institute 24-26 May 1960. (Edited by A. E. Mourant and F. E. Zeuner.) Pp. 166. (London: The Society, 1963.) $63 s$.

THE object of this symposium was to bring together facts derived from a wide variety of sourcesprehistoric, archæological, social background, geographical distribution and modern biochemical genetic techniquesbearing on the domestication and development of cattle.

Examinations of bones from Neolithic to Bronze, Iron and Middle Ages as compared with those of modern times show that considerable changes have occurred. These are illustrated by diagrams which show decline in size to the Iron Age and increase thereafter. Evidence bearing on the domestication of cattle is found in drawings, ornaments and figures made through the ages; although few of these are illustrated, references are given of where they can be found.

The social background of cattle varies greatly in different parts of the world. In the modern world cattle are valued for utility purposes, for milk and meat, but this is often a minor consideration among other peoples and primitive tribes. Being sacred to the Hindu, in India they are used for draught and milk only although tribes in the Himalayan area used them for meat and sacrifice. It has been said that in Africa the native attitude to cattle is "cowmania but not cowdolatry" in that they are used as a bank to purchase wives or other things required rather than for meat or draught. In ancient Crete they were valued for sport as they are in Spain to-day. An interesting paper, well illustrated by plates, is that on the exploitation of the milk-ejection reflex by primitive peoples when the semi-domesticated cows would not otherwise let their milk down to the milker. It is remarkable how their methods have been confirmed by recent scientific research. While the sight of the calf, or of a boy dressed in its skin, would cause the let-down of milk they found that in the absence of these milk could be obtained by blowing up the vagina with air by mouth. Research has shown that dilation of the vagina by the calf at parturition causes by neural stimulation the release of oxytocin from the posterior pituitary into the blood-stream and so causes not only contraction of the uterine muscles but also the basket cells surrounding the alveoli of the mammary gland, so causing the ejection of milk.

Two papers deal with the geographical distribution of breeds in both ancient and modern times. Relationship and movements of breeds are suggested by similarities in colour, shape of horns and other such Mendelian-inherited characters: these are illustrated by photographs. It is clear that the polled mutation has occurred in many places at different times but that it has only been used to create breeds in those areas where cattle have not been used for draught purposes. Of interest to those engaged in the development of the emergent African countries is the opinion that many of the native breeds have a good potential for meat production, but for milk production it will be necessary to cross them with European types to produce new breeds. This has already been done for beef breeds to suit tropical conditions, breeds such as the Santa Gertrudis, Bonsmara, Beefmaster, etc., combining the heat-tolerance of native breeds with the production qualities of European breeds. It is suggested that the hybridization of breeds and the crossing together of strains of the same breed developed in different parts of the world hold out promise for increasing production in both beef and milk. As examples of this the introduction of the Charollais and Red Danish breeds and importation of Friesians from Holland, South Africa and Canada into Britain are cited.

The possible contribution of biochemical genetics to the problem of the origin and relationship of breeds is discussed in several papers and is well illustrated by diagrams: extensive literature is also quoted. Just as blood grouping has been used to check pedigrees in cattle so the frequency of different blood groups, or better still the gene frequencies, are being used to indicate origins of breeds in various countries. Cattle hæmoglobin genotypes for different European and African breeds, as well as for the Jersey breed in different countries and for different levels of butter fat, are listed. Hæmoglobin patterns are also illustrated for different species and ages. Papers are also presented on milk protein polymorphisms for the lactoglobulins and lactalbumin in various breeds of British and African cattle.

The editing leaves something to be desired; similar subjects are not grouped, addresses of some of the authors are not stated, and figures quoted in the text do not always correspond with those on the plates.

JOHN HAMMOND 